\title{
Corporate Social Responsibility and Social, Economic and Environmental Development in Sri Lanka
}

\author{
Tilakasiri K.K. \\ Department of Accountancy, \\ University of Kelaniya, Kelaniya, Sri Lanka \\ ktilakasiri@kln.ac.lk
}

\begin{abstract}
This study reports Corporate Social Responsibility (CSR) and its present contribution of Sri Lankan context. CSR is renowned and known concept however, it is a new concept in Sri Lanka and research into this area relatively scarce compared with other Asian developing countries like India, Pakistan, Bangladesh, Indonesia, Malaysia and China. Furthermore, this study reveals complete on the theoretical development and the current CSR practices in Sri Lankan organisations, based on the literature and the researcher's CSR experience tried to achieve the research objectives which was to identify the basic activities of CSR that was implemented in the Sri Lanka's organisations.
\end{abstract}

Government and non-government organisations (NGO) have been implemented rules and regulations for community development, health and education development as well as environmental development, which are part of the CSR plans identified by international CSR 
standards. The government and the private sector both favour the adoption of CSR concepts, and are attempting to promote the implementation of CSR programmes in Sri Lanka.

Keywords: CSR , Social and economic environment, Sustainable development

\section{Introduction}

Corporate Social Responsibility (CSR) is renowned and known concept in the world wide organisations. However, CSR is a new concept in Sri Lanka and research into this area relatively scarce compared with other Asian developing countries like India, Pakistan, Bangladesh, Indonesia, Malaysia and China. However, some researchers have identified a number of CSR practices in Sri Lankan organisations (Rathnasiri 2003; Wickramasinghe 2006; Fernando 2007). According to them, the concept of CSR is used in Sri Lanka, although it is considered as only philanthropic. Sri Lankan companies, like the majority of companies in other Asian countries, regard CSR simply as being about charitable activities and providing financial assistance to various altruistic causes. However, the true concept of CSR is accepted as that stated in the recently released ISO 26000 Standard on Social Responsibility, as organisational governance, human rights, labour practices, the environment, fair operating practices, and also given consumer issues, with some attention to community involvement and development aspects'. Even though CSR 
practices in South Asian countries such as India, Thailand, Malaysia and China have been extensively investigated, in Sri Lanka, few such studies have been conducted. However, the concept of CSR is novel to Sri Lanka and its themes are compatible with the Buddhism practised there, in which the major theme is philanthropic giving. This study describes the impetus for the development of CSR in Sri Lanka, with Section 2 presenting an historical review of the country and Sections 3 and 4 describing the social and economic environment of the country, and capital market development. Section 5 highlights the challenges for sustainable development in Sri Lanka while the remaining sections include a discussion of CSR in Sri Lanka and its 97 regulations and guidelines. Section 6 presents corporate structure in Sri Lanka, Section 7 describes the development of CSR in Sri Lanka and Section 8 outlines the CSR-related regulations and guidelines in Sri Lanka. Finally, Section 9 describes the contribution of community and nongovernment organisations to the concept of CSR in Sri Lanka.

\section{History of the country}

Sri Lanka has more than 2,500 years of recorded history. For much of this time, Sri Lankan cultural, social, political, economic and technological life has been subject to dynamic changes. Before colonisation by the Portuguese, the country was an independent state with agriculture as the predominant economic activity. Before 1505, organisations that engaged in business were considered less socially acceptable (Chandraprema, 1989). Merchants from India, Arabia and 
China were the main travelers engaging in trade. However, during the period of colonisation from 1505 until 1948, the Portuguese, Dutch and British colonial rulers established a solid base for industry in Sri Lanka with the establishment of the Dutch-East India Company (Rathnasiri, 2003). Later, the British followed the Dutch system, which significantly influenced Sri Lanka as it is today. They restructured the Sri Lankan economy by shifting it from a subsistence agricultural economy to a trading economy based on tea, natural rubber and spices. Meanwhile private companies incorporated from the early to late 1800 s started the first Sri Lankan stock market (Rathnasiri, 2003). Since then, the number of companies listed by the Sri Lankan stock market has grown to include local and foreign companies including the John Keells Group, Aitken Spence, Browns and Company and Hayleys Group. Rathnasiri (2003) stated that with these developments, a dual economy began to emerge in the welldeveloped corporate export based sector and the mass agricultural based subsistence sector (based in rural areas). Yet, in Sri Lanka taken as a whole, the public attitude towards doing business has not significantly changed (Rathnasiri, 2003). Jayawardena (1974) stated that goods manufactured in Sri Lanka in the 1930s were mostly owned by the British and conformed to typical colonial patterns (e.g., tobacco, soap, candles, ice and soft drinks). Other industrial developments were directly geared 98 to economic activity in the plantations, largely in the public sector and consisting of workshops in the railways and public works departments. In the private sector, there 
were engineering workshops, which handled plantation machinery (Jayawardena, 1974). In 1948, the British announced full total responsible status for Sri Lanka within the British Commonwealth. Since then, private sector ownership has been transferred to the government and Sri Lanka has experienced an era of socialist-based, inward-looking development policies in which the government's ultimate responsibility was the welfare of the people. In the 1960s, all privately owned companies, including international companies (i.e. tea plantations), were nationalised due to people having lost faith in private enterprises (Rathnasiri, 2003). In 1972 a new constitution was adopted; as a result, Sri Lanka became a republic. In 1977, the new government established an open economy policy, allowing new opportunities for potential investors. Under the new political and economic policies the Sri Lankan government promised to refresh the agricultural sector, through developing local industrial production, growing self-employment, rising local investments and savings and increased the balance of payments in the medium term (Embuldeniya, 2000). This new package of reforms has been as a sweeping departure from tightly controlled, inward-looking, welfare-oriented economic strategy to a more liberalised, outward-looking and growth-oriented one (Central Bank, 1978, cited in Herring, 1987). Since this time the majority of the rural population in Sri Lanka has failed to receive the advantages anticipated by the change in government. Basic human needs, such as security, food, electricity and infrastructure (roads and telecommunications) are significantly underdeveloped. However, this 
is now changing due to the ongoing development programs initiated in 2003 by the present government. Another interesting observation is that there does not seem to be cohesiveness in the corporate sector as a whole, and the income distribution of the country is wide. Companies have been established in various ways due to competition and the people's interests. Conversely, people believe that companies engage in responsible business practices and if not, they campaign against them (CCC, 2005). Evidence shows that many Sri Lankan companies include CSR in their business strategies and that it has now become an integral part of local business for a range of reasons (CCC, 2005, p. 9). There is no agreement, as such, on what is socially responsible behaviour in Sri Lanka. Rathnasiri (2003) argued that this is looked upon more as a set of rules and regulations to be adhered to rather than from a values and behaviour point of view (p. 197). Voluntary adherence to a common set of norms in corporate behaviour is yet to be developed. Therefore, the CSR behaviour of the corporate sector in Sri Lanka should be understood within this context (Rathnasiri, 2003). The recent budget speech for the year 2012 proposed many programs for the social, environmental and economic development of the country. Considerable funds were granted to increase the activities of these three sectors. For example, under social integration, funds have been provided for the welfare of the elderly, support for low income families, the protection of women and children, conservation of wildlife and coastal preservation. This is the latest evidence that the government will encourage the development of CSR concepts. 


\section{The social and economic environment}

Sri Lanka is a developing country with a population of approximately 20 million. Over 40 percent of people engage in activities that depend directly on the environment, and around 25 per cent of the population live in urban or semi-urban areas. Sri Lanka has made considerable progress towards attaining a number of its Millennium Development Goals, such as access to education, gender equality and safe water and hygiene facilities. With a human development index in which the summary measure of human development is 0.658 (2010), Sri Lanka is ranked 91 among 177 countries. This indicates success in three basic elements of individual development; a long and strong life, ways to knowledge and a decent standard of living. Sri Lanka's gross domestic product (GDP) was approximately US\$50 billion in 2009. It has low levels of infant mortality and a life expectancy of 75 years. With a 93 percent literacy rate in local languages, it also has high levels of English communication, which assists in globalisation. The granting of free education facilities to the entire population has made the literacy increase to 93 percent levels possible and provided opportunity for both the rich and the poor to pursue higher education. Furthermore, the midday meal 100 programme and the supply of free books and uniforms for schoolchildren are the most popular programmes launched by the Government to further enhance the welfare package, which was implemented to improve the quality of education in the country. As a result, Sri Lanka is now ranked 91 out of 169 on the 
Human Development Index, and is one of the few low and middleincome countries that is achieving their millennium development goals (MDGs) at a national level. Sri Lanka's economy has grown at an average of 5 per cent over the past five years (Central Bank of Sri Lanka, 2010). In 2001 the country suffered its first ever recession, resulting in shortages of electricity, budgetary problems, international delay and ongoing civil conflicts. However, these problems were resolved after the ceasefire in 2002. In addition, since the end of the terrorism problem in 2009, the Sri Lankan capital market has risen and is now among the three best-performing markets in the world. In addition the per capita income rose from US \$841 to US \$2,250 over the same period. However, the government has now launched its economic development and poverty alleviation programmes in which the development of small and medium businesses has been prioritized. As a result, the government expects the country to retain macroeconomic steadiness and a regionally balanced economic growth rate. Siriwardena (2008) stated that over the next ten years, the country's per capita income level can be expected to rise to US $\$ 3,000$ and the growth rate of the economy to about 6-8 percent. Since Sri Lanka's economy has shifted to an agricultural export-orientated one relying on agricultural exports to fund the service and manufacturing sectors, the service sector accounts for more than 55 percent of GDP, with only one third of the workforce being engaged in agriculture (AusAid, 2011). 


\section{Sri Lanka's capital market}

Since liberalisation in 1977, Sri Lanka has been implementing open market orientated procedures and in the late 1980s introduced a plan to grow private sector investments and develop capital market, resulting in the incorporation of the CSE in 1985. This was a major development in the history of share trading in the capital market of Sri Lanka. Heenetigala (2010) stated that this has grown from Rs 263 billion to Rs 824 billion from 2003 to 2007, representing approximately 30 percent of the country's gross domestic product. The current key players in the Sri Lankan capital market are the CSE, local broker companies, Unit Trust Management Companies, market intermediaries, the Central Bank of Sri Lanka and some of the top listed local companies. As of June 2010, the CSE has 241 listed companies representing 20 business sectors. Santhush (2010) reported that as a result of this, in 2010, the CSE was one of the best performing markets in the world. Sri Lanka's capital market has developed more rapidly and extensively in the past two years than any other period in history (Sri Lanka Market Review, 2011). In a relatively short time-span, the capital market's role in funding and mobilising savings has become comparable to that of the highly performing Sri Lankan banking sector, firmly establishing its profile as an indicator and facilitator of growth within the Sri Lankan economy. This promising growth in the stock market has mainly been due to the stability of peace prevailing across the country after 26 
years of conflict. This unique development is an optimistic sign that shows Sri Lanka`s commercial background is shifting for the better, overflowing into the national economy. Government stability has now given investors a positive outlook, which has resulted in a strong growth momentum, which has been an important factor in the capital market with continued gains in the CSR indices.

\section{Challenges to sustainable development in Sri Lanka}

Since the 2004 tsunami disaster, Sri Lanka made impressive gains in providing access to basic social services (Fernando, 2010), resulting in significantly higher human development, in comparison to other developing countries. The human suffering experienced from the many years of armed conflict includes lost lives, disappearances, repeated displacement and dependencies on relief handouts, insecurity, fear, harassment, fragmented families and disrupted education. These circumstances have had a major negative effect on Sri Lankan society and the foundations of the social welfare of the country. These situations are no longer present as a result of the end of the war and the country is now working towards new development. However, the following social challenges also need to be overcome to better the lives of the people. 


\subsection{Poverty}

Despite the rapid development over recent years, Sri Lanka's income distribution intensity still shows an unacceptably large difference between rural and urban areas; about 15 percent of the country's population remains in poverty. The official reasons for this have been identified as the 26 years of civil conflict, declining rural and agricultural labour output, high inflation and poor infrastructure outside of the capital cities (Colombo, Gampaha and Kalutara), particularly in the Western Province where there is a severe shortage of infrastructure. Accordingly, the Media Centre for National Development of Sri Lanka (2011) stated that the Sri Lanka government is aiming to increase its per capita income up to US $\$ 4,000$ within the next six years. In Sri Lanka, the Northern, Eastern, Central, Uva and Sabaragamuwa provinces are the most severely affected. This is because one in four of the people in these areas are internally displaced (in the conflict-affected northern and eastern areas),

\subsection{Malnutrition}

Lack of nutrition is a serious problem, particularly for children in poor areas where one in five children under the age of five years has stunted growth (underweight). Half of the Sri Lankan population does not receive the recommended minimum calorie intake and government social welfare programs do not have enough money or funding to rectify the causes of malnutrition in children, including safe water, sanitation, maternal health and childcare practices (AusAid, 2011). 


\subsection{Education and health}

As described in Section 4.3, while Sri Lanka has publicly funded primary education for all children between the ages of six to 18 , there are large differences in learning outcomes across regions. This is because the quality of primary education is patchy, with many children having poor access to qualified teachers. Furthermore, tertiary and vocational education is limited and not well aligned to the needs of the labour market. 4.5.4 Reconstruction and development Reconstruction and development are major challenges in the conflict-affected areas. Using the Sri Lankan Central Bank report in 2010, AusAid (2011) declared that more than 100,000 homes need to be rebuilt. As a result, the Sri Lankan government is now focusing not only on education, but on building homes and increasing infrastructure in these communities.

\subsection{Peace, conflict resolution and reconciliation}

The 26 years of civil war were a major obstruction to sustainable development in Sri Lanka, and it affected economic growth with loss of human lives and widespread damage to property and infrastructure. This war absorbed large amounts of resources for defence, reconstruction and rehabilitation that could have been used more productively in other sectors. As a result of this situation, the government now faces huge economic problems if it is to develop the entire country including the post-conflict areas where many people are still internally displaced. 


\subsection{Realisation of social well being}

Social wellbeing is one of the three elements inherent for the sustainable development in Sri Lanka. General conditions of health, happiness, creativity and responsible fulfilment, health care, education, housing and urban development, safety nets, care for aged, good governance and the rule of law, all contribute to social wellbeing. Human development policies of successive governments have led to improvements in health indicators including low mortality and fertility rates, which are far ahead of other developing countries. However, there are regional inequalities, with higher mortality rates in the rural sector compared to the urban sectors. In the Mahinda Chinthana II (President's Vision), The Ministry of Environment and Natural Resources (2007) stressed the importance of rural development and agricultural 104 self-reliance (providing rural communities with access to markets, electricity and safe drinking water; investment in economic infrastructure and strengthened public service delivery). This reports pointed out that unplanned urban population growth has exerted pressure on land and water resources in the cities as well as surrounding areas, with impacts on sewage disposal, waste management, surface drainage and environment related health problems. The report estimated that by 2015 the urban population in Sri Lanka will increase from the present 30 percent to 45 per cent (Ministry of Environment and Natural Resources, 2007). Although the proper disposal and management of waste has been a 
major challenge in urban centres, the government has sought to the generate finances needed to improve the waste disposal system (Ministry of Environment and Natural Resources, 2007). As a result, since its institution in 2007 the economic development plan (Institute of Policy Studies Sri Lanka, 2007) has made significant progress towards achieving the management of waste. 4.6 Usefulness of the corporate social responsibility concept Chapple and Moon (2005) pointed out that many established CSR activities in the Asian region can be identified as traditional community involvement and socially responsible employee relations. This situation is similar in Sri Lanka. However, the government needs considerable funds to develop the country's infrastructure and to invest in capital projects such as maintaining roads, building highways and bridges, constructing buildings and other projects such as the provision of electricity, health care and education. Researchers (Fernando, 2010; Rathnasiri, 2003) have highlighted that the Sri Lankan companies are implementing CSR for philanthropic purposes. In addition to philanthropic responsibility, the companies should consider different CSR practices looking at global institutions. According to international CSR standards and practice, Sri Lanka needs to develop as follows:

1. Improve the quality and relevance of education at all levels and enhancing access to education; providing high quality, equitable, cost effective, modern and sustainable health care services. 
2. Structure modern, high standard and well-organised infrastructure services to improve access to input and output markets (i.e., roads, railways, ports, power and safe drinking water).

3. Promote the application of modern technology and R\&D to enhance competitiveness.

4. Modernise the legal and regulatory framework to promote the business environment. Government uses public funds for developing the above areas as public policy. Even though an increasing amount of funds has been devoted to these welfare activities over the past two decades, inflation, unemployment and the gap between the rich and the poor is still expanding in Sri Lanka.

The Ministry of Environment and Natural Resources (2007) has identified social, economic and environmental problems that need to be addressed, including severe land degradation, pollution and poor management of water resources, loss of biological diversity, coastal erosion, increasing scarcity of water for agriculture, inadequate facilities for waste disposal in urban areas and traffic congestion in the main cities. These problems provide an overview of the social, economic and environmental situation in Sri Lanka. To assist the government in solving these problems, it is necessary for the private sector to contribute to social welfare, in addition to the payment of their taxation levies. The people, employees and customers also 
indirectly affect the stability and growth of the private sector (Porter \& Kramer, 2002). Social and environmental projects could easily be implemented by the private sector to assist in sustainable development of the country.

\section{Corporate structure in Sri Lanka}

The present study relates to the publicly listed companies in Sri Lanka. These companies are listed by the CSE, which currently has are 20 sectors and 281 registered companies. Fifty (50) companies were selected from eight industries including: banking; insurance and finance; plantations; manufacturing; hotels and travel; beverage, food and tobacco; trading; telecommunications and diversified holdings. 106 The present study uses public limited companies as its sample, with, interviews conducted with the expert people from the community organisations for the framework development. This section describes the Sri Lankan corporate structure and identifies the CSR in those organisations. Corporate structure describes the ownership of organisations (Fan \& Wong, 2002), usually classified as governmentowned or privately-owned. In 1977 Sri Lanka's economy changed from public to private ownership. The ownership of Sri Lankan organisations can be categorised as either fully government-owned, semi-government-owned, public and groups, private companies, and individual-and family-owned companies. Government-owned organisations are appointed by the Minister of Cabinet of the relevant 
sector. The operational activities of these organisations are subject to government financial and administrative regulations (Balasooriya, 2004). Privately owned companies can be categorised as either as sole proprietor, partnership or corporations.

- Sole proprietorship: A sole proprietorship is a business owned by one person. The owner may operate on his or her own or may employ others. The sole proprietor has unlimited personal liability for the debts incurred by the business. This form is usually transferred to small businesses.

- Partnership: A partnership defines a form of business in which two or more people operate for the common goal of making profit. Each partner has total and unlimited personal liability for the debts incurred by the partnership. There are three typical classifications of partnerships: general partnerships, limited partnerships and limited liability partnerships.

- Corporation: A business corporation is a for-profit, limited liability or unlimited liability entity that has a separate legal personality from its members. A corporation is owned by multiple shareholders and is overseen by a board of directors, which hires the business's managerial staff. Corporate models have also been applied to the state sector in the form of Government-owned corporations. A corporation may be privately held (that is, held by a few people) or publicly traded. Presently, in Sri Lanka 
approximately 36,000 companies have been registered and 2,160 of these are publicly owned companies, while 281 are listed by the CSE. These companies are regulated by the Companies Act No. 7 of 2007 and many of them are limited liability companies (ADB, 2002 as cited in Balasooriya, 2004).

\section{Corporate social responsibility in Sri Lanka}

Stakeholders and other interested parties want to know about a company's social responsibility. Organisations are responsible for their actions with regards to both socioeconomic and environmental consequences. Many organisations in Sri Lanka, therefore, consider their socio-economic and environmental impact part of their responsibility while at the same time generating profit (Nanayakkara, 2010). Moreover, in a developing economy like Sri Lanka, the CSR concept plays an important role in the sustainable development discourse. This section discusses the development of the concept of CSR in Sri Lankan organisations and the ideas of various scholars in this field.

\subsection{Evidence of corporate social responsibility in Sri Lanka}

Recently, CSR has become a topic of discussion in the Sri Lankan corporate sector. Due to the country's serious economic problems the people, employees, customers and other interested parties put pressure on the government and business sector to improve the people's social 
and economic livelihoods. Most of Sri Lanka's private companies and groups of companies are run by families, and there is little evidence to show that these companies are engaged in philanthropic activities. Kumar et al (2002) pointed out that wealthy families tended to donate money for the renovation of Buddhist places of worship. An example of this was the renovation of the Kelaniya temple with funds donated by the Wijewardane family (p.3), and the people who made these types of donations are considered philanthropists. Fernando (2007) stated that private sector companies in Sri Lanka started to notice the results of CSR programmes after the Asian tsunami in 2004. Private sector companies are now the largest contributor to GDP in Sri Lanka, and most employees work in the private sector (Central Bank of Sri Lanka, 2010). Pressures for the implementation of CSR by this sector have arisen from employees, customers and competitors. There are two broad categories of CSR initiatives in Sri Lankan companies; externally focused approaches, and internal policy level approaches (Kumar et al., 2002; Rathnasiri, 2003). External CSR approaches focus on the public and carrying out public awareness programmes. For example, Union Assurance, an insurance company operating in Sri Lanka, has undertaken a public awareness campaign on general safety aimed at children. This campaign focus on precautions that should be taken when lighting fireworks during the festival season. Union Assurance has also conducted an awareness programme for school children on how to cross public roads safely in order to avoid accidents. A second example of externally focused CSR practices in 
Sri Lanka is that of Sampath Bank, a local commercial bank, which sponsors a public awareness campaign about preserving forests. Another local company, D. Samson Industries, a shoe manufacturing and distributing company, organised an island-wide school art competition with a view to enhancing the artistic skills of children. In general, Sri Lankan organisations are more concerned with externally focused CSR practices. Conversely, internal CSR programmes have been developed by companies according to the organisations interests. These include initiatives to provide better working conditions for employees, gender equality, equal opportunities, waste treatment, truth in advertising, preserving immediate environment and ethical dealings (Rathnasiri, 2003). However, the evidence available on CSR in Sri Lanka suggests that the traditional profit-maximising view is still prevalent according to Rathnasiri (2003). It appears that knowledge and understanding of CSR is limited in Sri Lankan organisations. Ariyabandu and Hulangamuwa (2002) have shown that four categories of CSR activities been formed in Sri Lanka. These were initiated by private sector organisations and include donations, environmental protection, community responsiveness and corporate sponsorships. According to these authors, donations were given by companies to support community service projects. These contributed towards food, clothing and shelter for the poor, gives assistance for surgical operations and towards relief in times of disasters such as floods, landslides and droughts. It is also instrumental in the homes 109 for elderly people, which was built by the organisation“ (Ariyabandu \& 
Hulangamuwa, 2002). Generally, company operational activities have an adverse impact on the environment, and hence they engage in environmental protection activities. Ariyabandu and Hulangamuwa (2002) showed that companies engaged in ongoing coast conservation projects, anti-pollution programs (river and air pollution), eco-friendly business (solar water heaters, industrial safety equipment, effluent treatment chemicals and specialised plastic bottles), and soil conservation activities, organising seminars for public awareness on environmental conservation'. Further, Ariyabandu and Hulangamuwa (2002) stated that under public awareness programmes, companies instituted safety programmes, informing the public of natural disasters, providing health information (e.g. dengue fever epidemics) and informing religious activities. Finally, Ariyabandu and Hulangamuwa (2002) pointed out that the corporate sponsorships for the young children in education, providing scholarships for the higher education of students, supporting services to disabled people, are common social activities in Sri Lankan organisations. A study comparing CSR in two Sri Lankan companies implementing post-tsunami related CSR activities was Fernando's (2007). His research made several suggestions for the theory and practice of CSR in Sri Lanka. He proposed a conceptual model, and examines virtuousness as a necessary attribute of genuineness in tsunami related CSR initiatives. Fernando's (2007) study provided good evidence for understanding CSR in Sri Lanka by showing publicity was the major reason for implementing CSR in Sri Lanka under the post-tsunami CSR 
initiatives. The two companies were more concerned with focusing on CSR after the tsunami in Sri Lanka. One company focused on community-based projects and the other focused on environmentally based programmes. Fernando stated that these companies had attempted to balance economic, legal and ethical considerations and reacted in different ways. He also pointed out the two companies have developed CSR initiatives based on the aggregation of firms differing resources and capabilities (a resource based interpretation). International Alert (2005) found the majority of companies in Sri Lanka would like to apply the concept of CSR; however, they have no clear guiding principles to follow. They also stated that companies genuinely want to contribute to society by improving the quality of life of people; therefore, they practice CSR. However, if the corporate sector is genuinely interested in investing in CSR projects they should address the real issues of Sri Lankan society with a rational approach for this to be more effective and fruitful (Fernando, 2010; Rathnasiri, 2002; International Alert, 2005). These social issues include the alleviation of poverty, health, education, employee and consumer rights and environmental problems. 


\section{Corporate social responsibility regulations and guidelines}

CSR operates on a voluntary base in Sri Lanka. However, Sri Lankan companies are using the communication of CSR as a proxy for CSR activities. While voluntary disclosure of CSR activities by Sri Lankan organisations is common, it is not a mandatory requirement (Abeysekera \& Guthrie, 2004, 2005; Bebbington et al., 2009). All listed companies have documented their CSR contributions and activities in separate sections of their annual reports according to the policy of the Sri Lanka Accounting and Auditing Standards Board, adopted in 2004. Sri Lankan companies use IFRS to prepare their financial statements (Khan, 2006). In addition, a Code of Best Practice on Corporate Governance was developed by the ICASL and the SEC, in consultation with the CSE. The major aim of the development of the code of best practice was to improve corporate governance practices in Sri Lanka. Further, the Sri Lanka Accounting and Auditing Standard Act No. 15 of 1995 gave power to the ICASL to approve SLAS and SLAuS for the Sri Lankan organisations. This act was also in order to constitute an independent Sri Lanka Accounting and Auditing Standards Monitoring Board (SLAASMB) to perform auditing functions. Further, the Act utilised all the SBEs to organise company income statements in accordance with the SLAS. Heenetigala (2010) explained that the SLAASMB now monitors the compliance of accounting and auditing standards as set out in the Act. According to Kolk et al (1999) the codes of conduct are encompass[ing] guidelines, 
recommendations or rules issued by entities within society (adopting body or actor) with the intent to affect the behaviour of (international) business entities (target) within society in order to enhance corporate responsibility (p.151). Furthermore, differences among the international codes and internal codes were identified by Kolk et al (1999). Bondy et al (2008) differentiated the two general types of codes as voluntary and mandatory. They viewed of the mandatory codes as a requirement for corporations determined by governing bodies such as governments (e.g. German Corporate Governance Code, Canadian privacy legislation), financial regulating bodies (e.g. UK Combined Code), or by industry association bodies (Responsible Care in the chemical industry, (p. 296). In the above paragraph financial regulating bodies which are well recognised in Sri Lanka were highlighted. In addition, codes of conduct have been introduced by the Si Lankan government, now encompassed as rules. Evidence of CSR activities in Sri Lankan companies can be obtained from corporate websites, company annual reports as well as corporate sustainability reports. Since 2004, a number of listed companies have engaged in CSR activities. Presently, many companies believe CSR to be a significant contributing factor in their business operations. Therefore, the enclosure of a social responsibility statement in their annual reports is common in Sri Lankan companies (International Alert, 2005). Organisations must observe rules and regulations in relating to employees, customers and environmental factors, not simply the CSR-related regulations. However, these rules and 
regulations imply the need for social and environmental activities related to CSR.

\subsection{The Ceylon Chamber of Commerce}

The Ceylon Chamber of Commerce (CCC) was established in 1839 as an independent, non-profit and non-political voluntary body. The CCC is an important point of contact for business, both locally and internationally. The Chamber's membership ranges from sole proprietors to multi-national companies and it includes virtually every sphere of economic activity in Sri Lanka. Currently, the CCC is concerned with promoting CSR practices in Sri Lankan organisations. They develop and popularise CSR concepts in both the private and public sectors, providing international CSR issues and standards. The Ceylon Chamber of Commerce (2005), on the other hand, introduced the following social issues for developing the CSR capacity of Sri Lankan organisations: respect for human rights, socio-economic development, employee welfare, consumer protection, respect for national sovereignty, resource sharing, community investment and socially responsible investment. With respect to environmental issues, the CCC recommends that environmentally friendly technology, ecofriendly waste disposal, prevention of environmental pollution, preservation of biodiversity, coastal preservation and management activities to be employed. Since 2004, the CCC has also organised an annual competition for the best corporate citizen for participating 
private and public organisations. The assessment criteria for this competition are based on five stakeholder issues: environmental responsibility, employee relations, customer and supplier relations, community relations, and good governance and economic contribution. Both public and private sector enterprises are eligible to apply for the awards.

\subsection{The STING Consultants}

The STING consultants (2002) are a recently incorporated service organisation in Sri Lanka, providing marketing and brand consulting services. They have developed a corporate accountability-rating index that has operated since 2009; it focuses on assessing the level of an individual business's ability to understand and take up a strategic accountability programme. This index is open to all organisations that wish to measure their CSR effectiveness. The index includes six key areas: corporate values; stakeholder engagement; identifying impacts, risks and opportunities; policy coverage; management and governance; and measurement and disclosure. The index ranked 66 companies in 2011 and 65 companies in 2010. In addition, STING Consultants instruct organisations to use the GRI Guidelines for reporting CSR in their publications. As part of this commitment, STING compiled a database of sustainability reports based on the GRI guidelines that have been published by local companies to date. 


\subsection{The Sri Lanka Red Cross Society (SLRCS)}

The Sri Lanka Red Cross Society has operated since 1936 and adopted a new constitution and organisational changes in 2002. The SLRCS covers all administrative districts of the country and its 6,500 members are all volunteers. SLRCS's vision is safer, resilient and socially inclusive communities through improving lifestyles and changing mind-sets “ (Sri Lanka Red Cross, 2011, http://www.redcross.lk/idp), and their mission is reduce risk, build capacity and promote principles and values by mobilising resources, creating universal access to services through volunteerism and partnership“ (Sri Lanka Red Cross, 2011, http://www.redcross.lk/idp). Their principle values are humanity, impartiality, neutrality, independence, voluntary service unity and universality. One of the key programmes of the SLRCS is disaster management, which aims to improve community capacity to cope with and manage disasters, while continuing to maintain organisational readiness to respond to natural and manmade disasters. Their other major role is to provide support for displaced people. Here, their work with the UN to construct new houses following the ownerdriven approach is the key constituent of the programme, while other components such as the provision of clean water and sanitation, community infrastructure, livelihoods, health care, disaster management and organisational development complement the sustainability and the resilience of the community. In addition, the Red 
Cross plans to undertake the support activities under the seven sections listed below:

- Shelter and non-food relief items (NFRI) assistance, , Water and sanitation, - Health - Education and sports, - Service provision - Food security, agriculture and livelihood - Mine action and economic development.

In addition, the Red Cross supports people by providing welfare services. During the 26 years of civil war endured by Sri Lanka, which ended in 2009 following the military defeat of the Tamil Tigers, thousands people lost everything savings, properties, shelter, education and health. The Red Cross now supports these civilians under a postconflict reconstruction programme designed to improve their lifestyles. The following community services operate under this programme:

- Shelter: safe and adequate shelter and settlement solutions through the provision of cash grants and guidance on improved building techniques.

- Health care: provision of community-level preventive and curative services with the intention of reducing the health risks of the affected population. 
- Water and sanitation: provision of safe water and adequate sanitation as well as the promotion of good hygiene to reduce the risk of waterborne and water related diseases.

- Livelihoods: assist displaced families in replacing, repairing, reestablishing, strengthening and sustaining their household income.

- Disaster management: create awareness among local communities on local risks and resources available and prepare and equip them to respond to disasters.

- Organisational Development: capacity building of the branchlevel structures in the Kilinochchi and Mulativu districts to provide effective support for the local population to improve community resilience, to develop healthy lifestyles, prepare for disasters and respond to emergencies.

\subsection{The Ministry of Health}

The vision of the Ministry of Health for Sri Lanka is a healthier nation that contributes to its economic, social, mental and spiritual development". Under this vision the ministry aims to empower the community for maintaining and promoting their health, to improve comprehensive health services delivery and health actions, to strengthen stewardship and management functions, to improve the management of human. In addition, that they have introduced the following sub-objectives to achieve these goals: 
- To assist and develop IEC/BCC materials required for health promotion and behaviour change communication.

- To develop the capacity, both within and outside the Department of Health Services, to act as health promoters and change agents through advocacy, behaviour change communication and social mobilisation.

- To educate and empower the public on health issues, to enable them to increase control over and promote individual and community health.

- To coordinate with health-related government, non-government and international agencies and organisations in promoting the health of the people.

- To develop the managerial capacities of the health and healthrelated sectors to manage health promotion programmes.

- To monitor and evaluate health promotion programmes and facilitate their monitoring and evaluation at different levels.

- To support and undertake research related to behaviour change in the community and social mobilisation. 


\subsection{The Ministry of Education}

Sri Lanka's education system is based on the British education system introduced by the British colonial masters in the 19th century. This system is now under the control of the Ministry of Education, another government public welfare organisation. Their mission is to -develop competent citizens in keeping with the global trends through innovative and modern approaches to education leading to efficiency, equity and high quality performance ensuring stakeholder satisfaction\| (Education System Profile, 2012). Sri Lanka's education system is free for all citizens from Grade 1 to university level. In addition, the country has other tertiary education systems such as technical colleges, nursing schools, teachers colleges and higher diploma schools that operate under the control of the Ministry of Education. The role of the private sector is limited to the provision services to the education system. However, the limited resources available cannot be provided equally to all districts in the country and therefore the education systems in Sri Lanka is highly competitive, from the Grade 5 scholarship examination, through to the Grade 10 ordinary level examination to the Grade 12 advanced level (university entrance) examination. The following welfare services are provided by the Ministry of Education:

- Free education from Grade 1 to university level $\bullet$ Free text books from Grade 1 to Grade 12 
- Free school uniforms - Subsidised transport - Bursaries for deserving students from Grade 5 up to university $\bullet$ Midday meals for primary students in identified schools • Free medical inspections in schools, and the provision of dental care and free spectacles to needy children

To maintain the quality of Sri Lanka's education system the following teacher training schools have been established:

- 17 National Colleges of Education - 9 Teachers ${ }^{6}$ Colleges for teachers training $\bullet 100$ Teachers $^{\star}$ Centres for continuing teacher education $\bullet 4$ Faculties of Education in universities

The following programmes have been employed to develop the education system and improve the quality of education in Sri Lanka:

- Curricular reforms: child-centred activity based relevant curricula Improving the validity and reliability of examinations $\bullet$ School-based assessment (SBA) • Teacher development • Better textbooks Promoting value education-democratic ideals, pluralism, social cohesion - The use of ICT in education To maintain and further develop the quality of education in Sri Lanka, private international schools and universities are being introduced, complementing the existing education system. 


\subsection{The Consumer Affairs Authority}

The Consumer Affairs Authority (CAA), which falls under the Ministry of Trade Commerce, Consumer Affairs and Marketing Development, is the main government institution mandated to protect consumers against unfair trade practices and safeguard fair market competition in Sri Lanka. In Sri Lanka, consumer protection is addressed by a variety of methods, such as consumer education programs and complaint mechanisms. Within the CAA, the Consumer Affairs and Information Division is responsible for promoting the establishment of consumer organisations and encouraging consumer education, which has mainly consisted of programs and competitions for schoolchildren and messages in the mass media. The Sri Lankan Legal Aid Commission, an independent statutory body, has a Consumer Protection Desk, linked closely with the CAA. The consumer protection desk conducts nationwide consumer awareness programs and gives legal advice to aggrieved consumers seeking redress from the CAA. The CAA was established under Consumer Affairs Authority Act No. 9 of 2003 and the Consumer Affairs Council (CAC) as the government body with control over consumer protection and business competition in Sri Lanka. It extensively regulates the sale of goods, as well as regulating services, which include banking and financial services. The Act gives the CAA and CAC quasi-judicial powers to investigate consumer complaints 120 and enforce the act, while also authorising courts to impose substantial monetary penalties and/or imprisonment for violations of the Act. 


\subsection{Department of Labour}

The Department of Labour is linked to the Ministry of Labour in Sri Lanka and their mission is to engage with the labour development process through behavioural work environment within secured industrial peace All employers in Sri Lankan organisations must respect the labour law and other related laws and regulations issued by the Ministry of Labour and the Department of Labour. These rules protect employees' welfare, and many of their actions are similar to the international labour laws issued by the ILO. The main activities of the Department of Labour in Sri Lanka (Department of Labour 2011) are as follows:

- Enforcement of labour laws and settlement of industrial disputes

- Implementation of social security schemes - Monitoring occupational hygiene and the prevention of industrial accidents - Regulating the employment of persons, undertaking planning and research in the field of labour, educating social partners with a view to promoting employer - employee relations - Labour market information services - Collection, compilation and dissemination of labour statistics • Registration of trade unions • Working closely with the Ministry of Labour Relations and Manpower in fulfilling Sri Lanka's obligations as a member of the ILO During the period of 85 years, over 40 pieces of legislation have been enacted for the protection and welfare of labour, covering a wide spectrum of activities. 
The implementation of these laws has been the task of the Department. In addition, the Department has also been involved in activities such as worker education, human resources placement, labour market information, social dialogue and monitoring complaints and the social development and quality of work life (Department of Labour, 2011). In addition to observing these welfare and employee protection laws, many 121 organisations in Sri Lanka practise a variety of social activities as will be explained in Chapters 7 and 8 .

\subsection{The Central Environmental Authority}

The Central Environmental Authority (CEA) was established in August 1981 under the provision of the National Environmental Act No. 47 of 1980. The Ministry of Environment and Natural Resources (ME\&NR), which was established in December, 2001, has the overall responsibility for the affairs of the CEA with the objective of integrating environmental considerations in the development process of the country. The CEA was given wider regulatory powers under the National Environment (Amendment) Acts No. 56 of 1988 and No. 53 of 2000. The mission of the CEA is to be the flagship of the nation steering towards protecting and managing the quality of the environment by promoting public participation, enforcement, advanced technological interventions \& environmental education (Central Environmental Authority, 2011). The CEA comprises three divisions; Environmental Pollution Control, the Environmental 
Management and Assessment and the Environmental Education Awareness. The Environment Education and Awareness Division is responsible for creating and improving awareness and providing public education with the aim of obtaining participation in the environmental conservation process. The Education and Awareness Division has implemented many programs for various groups have implemented many programs for various groups to help achieve objectives such as social and environmental activities for schoolchildren and in other educational centres. The Division is comprised of the National Environment Information Centre, the HRD, Administration and Finance Division, the Legal Division, the Planning and Monitoring Unit and the Internal Audit Unit. Moreover, many social and environmental activities promote for the schoolchildren and other educational centres under the above unit.

\section{Conclusion}

In this study CSR and its present contribution of the Sri Lankan context has been discussed. Government organisation and nongovernment organisations (NGO) have implemented rules and regulations for community development, health and education development as well as environmental development, which are part of the CSR plans identified by international CSR standards. The information available highlights the fact that CSR is necessary to fulfil a company's responsibility to society, their employees and customers. 
International Alert (2005) has explained that the majority of Sri Lankan companies wish to implement CSR programmes but they have no clear guidelines to follow. However, the majority of the companies in Sri Lanka already engaged in CSR practices do so because they genuinely wish to contribute to the betterment of society (International Alert, 2005). There is no mandatory requirement to practise CSR in developing countries, even though many private and public sector organisations have placed CSR into practice since 2003. The academic literature therefore provides justification for the regulation of CSR in terms of protecting the interests and rights of stakeholders where these diverge from the economic rights and interests of shareholders (Unerman \& O`Dwyer, 2007). Bondy et al., (2008) stated CSR codes are primarily connected with the CSR practices of an organization. They had little empirical supported for the link between codes and CSR. Thus, they suggested if a corporation has a code, it is more likely used to govern traditional business concerns, such as compliance with third party governance requirements, internal issues such as conflict of interest, bribery and corruption, insider trading, etc.( Bondi et al., 2008, p.294). Nevertheless, CSR implementation is costly. The Sri Lankan government needs to devote more funds to welfare activities for improving health, education and shelter. If the government does not facilitate community development then people will put pressure on it to meet their basic needs. Further, when private sector organisations do not consider responsibilities toward their stakeholder, they will face the same pressures, for example, product boycotts, employee pressures 
and customer pressures. 123 The CCC supports private sector organisations to implement CSR in their organisations. The Ministries of Education, Health, Labour and Consumer Protection, and Environmental Protection are widely recognised institutions; they have strategic plans to advance development through increasing social responsibility activities aimed at improving social and human welfare in Sri Lanka. The government and the private sector both favour the adoption of CSR concepts, and are attempting to promote the implementation of CSR programmes. Consequently, CSR is very popular and will have many positive effects on the country as a whole. Therefore, it is necessary to establish standards and guidelines for CSR in the Sri Lankan context (Rathnasiri, 2003; Fernando, 2010). Accepted measurement standards will enable the development of a rating system based on specific industries. 


\section{References:}

Abeysekera, I., \& Guthrie, J. (2004). Human capital reporting in a developing nation', The British Accounting Review, vol. 36, no. 3 , pp. 251-68.

Ariyabandu, M.M., \& Hulangamuwa, P. (2002). Corporate Social Responsibility and Natural Disaster Reduction in Sri Lanka'.

Aus A. (2011). Australia's strategic approach to aid in Sri Lanka 2011-2015‘. Accessed on 2011.11.15 http://www.ausaid.gov.au/publications/pdf/strat-approachsrilanka-2011-15.pdf

Balasooriya, L. (2004). The impact of corporate governance on productivity in Sri Lanka, Asian productivity organisation Tokyo, viewed 12.07.2009

Bebbington, J., Higgins, C., \& Frame, B. (2009). Initiating sustainable development reporting: evidence from New Zealand', Accounting, Auditing \& Accountability Journal, vol. 22, no. 4, pp. 588-625

Bondy, K., Matten, D., \& Moon, J. (2008). Multinational corporation codes of conduct: governance Tools for Corporate Social Responsibility?‘ Journal Compilation, Vol 16, no.5, pp.294311

Central Bank of Sri Lanka, C 2010, Annual Report', viewed 1.1.2011,

Chandraprema, C. (1989). Ruhuna: A Study of the History, Society \& Ideology of Southern Sri Lanka, Bharat. 
Embuldeniya, D.K. (2000). Economic reforms and the corporate sector in Sri Lanka', Contemporary South Asia, vol. 9, no. 2, pp. 165-79. Fernando 2007

Fernando, M. (2007). Corporate Social Responsibility in the Wake of the Asian Tsunami: A Comparative Case Study of Two Sri Lankan Companies', European Management Journal, vol. 25, no. 1, pp. 1-10.

Corporate social responsibility in the wake of the Asian tsunami: Effect of time on the genuineness of CSR initiatives',(2010). European Management Journal, vol. 28, no. 1, pp. 68-79

Heenetigala, K. (2010). Corporate governance practices and firm performance of listed companies in Sri Lanka', Doctor of Philosophy thesis, Victoria University.

International Alert, (2005). Peace Through profit: Sri Lankan perspectives on corporate social responsibility', viewed 20.09.2009, http://www.internationalalert.org/pdf/peace_through_profit_sri_lanka_csr.pdf

Jayawardena, V.K. (1974). Origins of the Left Movement in Sri Lanka', Social Scientist, vol. 2, no. 6/7, pp. 3-28.

Jayawardena, V.K. (1974), The rise of the working class in Sri Lanka $\&$ the printers strike of 1893 s.n. (s.1.) Colombo

Kolk, A., Van Tulder, R., \& Welters, C. (1999). International codes of conduct and corporate social responsibility: Can transnational corporations regulate themselves?, Transnational Corporations, vol. 8, no.1,pp. 143-80. 
Nanayakkara, M.S. (2010). Socio-economic of Corporate Social Responsibility practices in Sri Lankan domestic manufacturing companies', Master Thesis, The University of Agder.

Rathnasiri, H. (2003). Corporate Social Responsibility Practices of Sri Lankan Private Sector: An Exploratory Study', Sri Lanka Journal of Management, vol. 8, no. 3-4, pp. 195-228

Santhush, F. (2010). Sri Lanka's Colombo Stock Exchange cited as world's best performing bourse', Asian Tribune, vol. 11, no. 136, viewed 2010.05.12, http://www.asiantribune.com/news/2010/10/03/sri-lankascolombo-stock-exchange-citedworlds-best-performing-bourse

Siriwardena, C.J.P. (2008). Bond Market development in Sri Lanka, Central Bank of Sri Lanka, Colombo

The Ministry of Environment and Natural Resources (2007)

Unerman, J., \& O`Dwyer, B. (2007). The business case for regulation of corporate social responsibility and accountability', Accounting Forum, Vol.31, pp. 332-353 